Blombäck, B., and Blombäck, M. (1957). Ark. Kemi., 10, 415.

Burt, J. J., Blyth, C. S., and Rierson, H. A. (1964). 'J. Sport Med. (Torino), 4,213 .

Cardon, P. V., jun., and Gordon, R. S., jun. (1959). F. psychosom. Res., 4,5 .

Cash, J. D. (1966). Brit. med. F., 2, 502

Dreyfuss, F. (1956). F. psychosom. Res., 1, 252.

Duguid, J. B. (1949). Lancet, 2, 925.

Enos, W. F., Holmes, R. H., and Beyer, J. C. (1962). Amer. F. Cardiol., 9, 343 .

Fearnley, G. R. (1965). Fibrinolysis, p. 58. London.

Balmforth, G., and Fearnley, E. (1957). Clin. Sci., 16, 645.

and Lackner, R (1955). Brit. 7. Haemat., 1, 189. Fletcher, A. P., Biederman, O., Moore, D., Alkjaersig, N., and Sherry,

Friedman, M., Rosenman, R. H., and Carroll, V. (1958). Circulation, 17, 852.

Hickam, J. B., Cargill, W. H., and Golden, A. (1948). F. clin. Invest., 27, 290 .

Hume, R. (1958). Brit. Heart f., 20, 15.

Iatridis, S. G., and Ferguson, J. H. (1963). F. appl. Physiol., 18, 337

Innes, D., and Sevitt, S. (1964). \%. clin. Path., 17, 1.

Jang, E., Fletcher, B. T., and Bickford, A. F. (1964). Clin. Sci., 27, 9. nuszko, T. Furman, M., and Buluk, K. (1966). Thrombos. Diathes. haemorrh. (Stuttg.), 15. 554 .
Katz, A. M., McDonald, L., Davies, B., and Edgill, M. (1963). Lancet,

1, 801 ., ackner, H., and Merskey, C. (1960). Brit. F. Haemat., 6, 402.

Macfarlane. R. G., and Biggs, R. (1946). Lancet, 2, 862.

Macht, D. I. (1952). F. Amer. med. Ass., 148, 265.

MacKay, N., and Hume, R. (1964). Scot. med. f., 9, 359.

Myasnikov, A. L. (1958). Circulation, 17, 99.

Naimi, S., Goldstein, R., and Proger, S. (1963). Ibid., 27, 904.

Nestel, P.' J. (1960). Aust. Ann. Med., 9, 234.

Nolf, P. (1908). Arch int. Physiol., 6, 306.

Ogston, D. (1962) Brt. med. Y., 1, 1242

Ogston, D. (1962). Brit. med. F., 1, 1242.

- (1964). 3. psychosom. Res., 8, 219.

- and McAndrew, G. M. (1964). Ibid., 2, 1205

McDonald, G. A., and Fullerton, H.' W. (1962). Ibid., 2, 521.

Owren, P. A. (1947). Acta med. scand., 128, Suppl. No. 194.

Patsch, J. (1963). Wien. med. W schr., 113, 537.

Ratnoff, O. D., and Menzie, C. (1951). 7. Lab. clin. Med., 37, 316.

Remmert, L. F., and Cohen, P. P. (1949). 7. biol. Chem., 181, 431.

Rokitansky, C. von (1852). A Manual of Pathological Anatomy. London.

Schneider, R A. (1951). Amer. F. med. Sci., 222, 562.

Sherry, S., Lindemeyer, R. I., Fletcher, A. P., and Alkjaersig, N. (1959). 7. clin. Invest., 38, 810 .

Texon, M. (1957). Arch. intern. Med., 99, 418.

Truelove, S. C. (1951). Clin. Sci., 10, 229.

\title{
Hypophysitis and Hypopituitarism: Report of a Case
}

\author{
R. HUME, ${ }^{*}$ M.B., M.R.C.P.ED., M.R.C.P.GLASG. ; G. HEFIN ROBERTS, $\dagger$ M.B., B.SC., M.C.PATH., D.PATH.
}

So far as we are aware, anterior hypophysitis has been described only once previously (Goudie and Pinkerton, 1962). It seemed of interest, therefore, to report a further case in which the patient, a known case of pernicious anaemia, was found at necropsy to have not only hypophysitis but also chronic atrophic gastritis, focal lymphocytic thyroiditis, and adrenal atrophy.

\section{Case Report}

A nulliparous spinster aged 74 who had an uneventful menopause at the age of 50 was first admitted to the Southern General Hospital in June 1963, when a diagnosis of pernicious anaemia was made on the basis of a macrocytic anaemia, megaloblastic erythropoiesis on sternal marrow examination, histamine-fast achlorhydria, low serum vitamin-B $B_{12}$ level $(25 \mu \mu \mathrm{g} . / \mathrm{ml}$.), and a normal response to the administration of cyanocobalamin. At that time extreme pallor of the skin was remarked upon, and this continued to be a striking feature even when the haemoglobin had returned to normal. She was observed as an outpatient until August 1964, and, though haematologically normal, never regained her former energy. On one occasion hypopituitarism had been suggested to account for her appearance. This possibility had not been investigated further.

On 6 February 1966 she was readmitted to the Southern General Hospital, having been found unconscious at home. During the preceding three weeks she had become progressively more drowsy and mentally confused. Promazine had been prescribed two days before admission. The clinical features of note were extreme pallor and waxy appearance of the skin in spite of a haemoglobin of $13 \mathrm{~g} . / 100 \mathrm{ml}$. Head hair was fine and dry and body hair was scanty. Skin temperature was $94.8^{\circ} \mathrm{F}$. $\left(34.9^{\circ} \mathrm{C}\right.$.) and the blood pressure $70 \mathrm{~mm}$. Hg systolic ; the diastolic pressure was not recordable. Serum electrolyte measurements revealed a low sodium and chloride level ( $\mathrm{Na} 122 \mathrm{mEq} / \mathrm{l} ., \mathrm{Cl} 80 \mathrm{mEq} / \mathrm{l}$.) and normal potassium $(4.3 \mathrm{mEq} / \mathrm{l}$.). Serum urea was raised $(73 \mathrm{mg} . / 100 \mathrm{ml}$.) and blood sugar level normal (94 mg./100 ml.). The electrocardiogram revealed QRS, ST, and T changes compatible with hypothyroidism.

In view of the clinical picture suggesting hypopituitarism treatment was begun with hydrocortisone $100 \mathrm{mg}$. intravenously

* Consultant Physician, Southern General Hospital, Glasgow S.W.1. t Consultant Pathologist, Southern General Hospital, Glasgow S.W.1. eight-hourly and triiodothyronine $10 \mu \mathrm{g}$. twice daily. Next day the patient was rousable, the skin temperature had returned to $97.2^{\circ} \mathrm{F}$. $\left(36.2^{\circ}\right.$ C.). and the systolic blood pressure was $100 \mathrm{~mm} . \mathrm{Hg}$. Progress was continuing satisfactorily; the patient had become conscious but was still irrational, her temperature was normal, and the blood pressure $120 / 70 \mathrm{~mm}$. $\mathrm{Hg}$, when suddenly on 11 February she died, five days after admission.

\section{Necropsy Findings}

The body was that of a well-nourished pale old woman; body hair distribution did not appear grossly abnormal for a woman of 74. Internally the relevant findings were confined to the lungs, pituitary, adrenals, stomach, and thyroid.

The left lung was dark, firm, and heavy (580 g.); there was confluent bronchopneumonia of the lower lobe and along the posterior margin of the upper lobe.

The pituitary was a small flat organ approximately one-third the normal size and covered with a slightly thickened capsule. Both adrenals were atrophied (combined weight $5 \mathrm{~g}$.) and deeply embedded in periadrenal fat. The thyroid was slightly atrophied; both lobes were finely nodular and showed numerous small gritty foci of calcification.

The mucosa of the body of the stomach was severely atrophied, the pyloric mucosa looked normal, and the uterus and ovaries were normal for a woman of her age.

\section{Histological Report}

Pituitary (Figs. 1 and 2).-The pars posterior is normal and the capsule shows fibrous thickening. The pars anterior is less than one-quarter of its normal size and shows lymphocytic infiltration, acinar atrophy, and fibrosis. The lymphocytic infiltration is heavy and diffuse ; only the occasional plasma cell is present ; no giant cells can be seen. The cellular infiltration is particularly heavy around groups of atrophied acini. Though a few small dense focal aggregates of lymphocytes are present, no true follicles with active germinal centres are seen. Only scattered groups of acini remain-some large, others small. In some areas the glandular tissue consists only of scattered single epithelial cells surrounded by 
lymphocytes. The fibrous tissue shows dense hyaline acellular areas mixed with more cellular fibroblastic connective tissue. Staining for amyloid gives negative results.

Thyroid (Fig. 3).-Sections show a fine nodular pattern, owing to increase of interlobular fibrous tissue. Scattered throughout both lobes are numerous small areas of focal chronic thyroiditis,

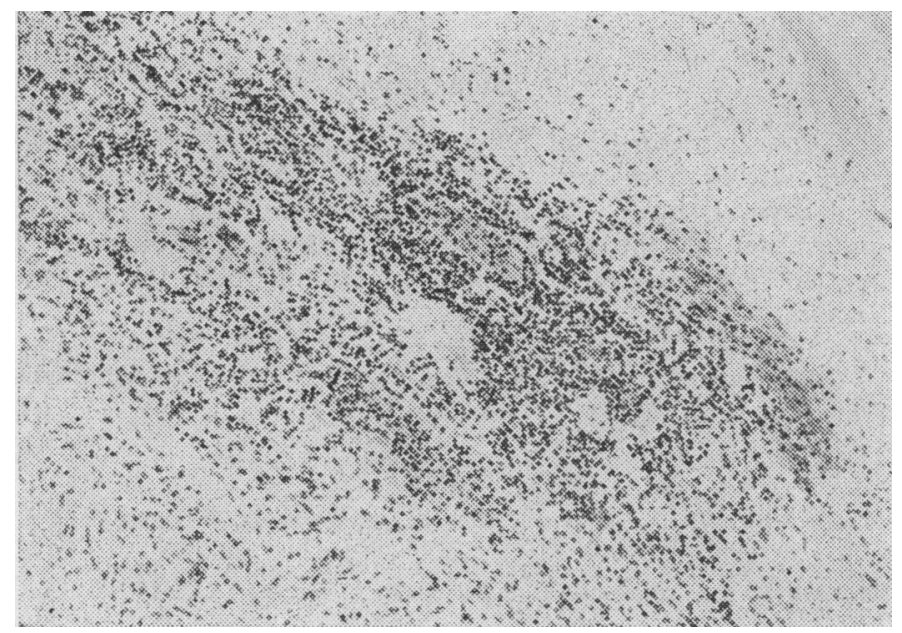

FIG. 1.-Anterior lobe of pituitary. Diffuse lymphocytic infiltration and glandular atrophy. (H. and E. $\times 120$.

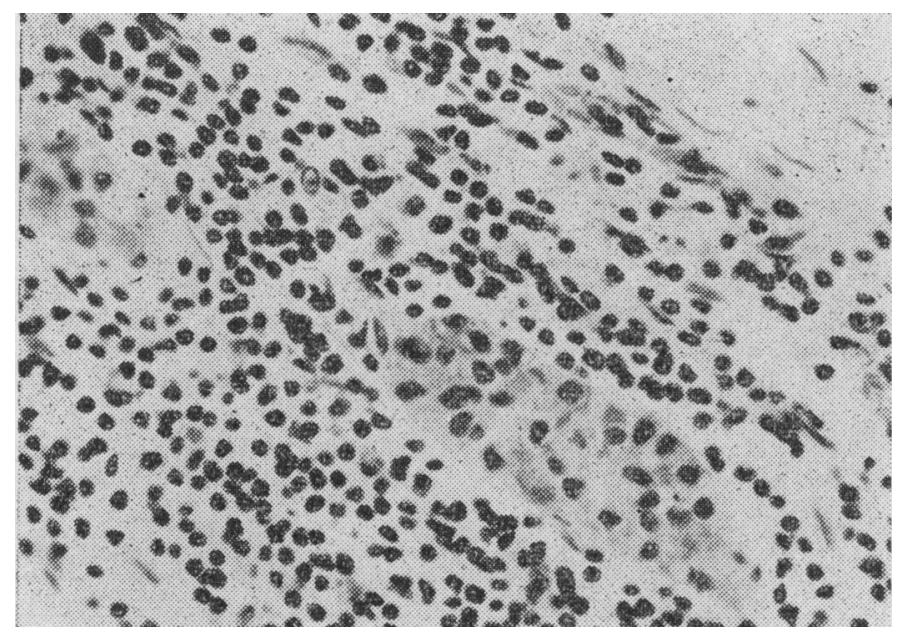

FIg. 2.-Anterior lobe of pituitary. Atrophied acini surrounded by lymphocytic infiltration. (H. and $\mathrm{E} . \times 480$.)

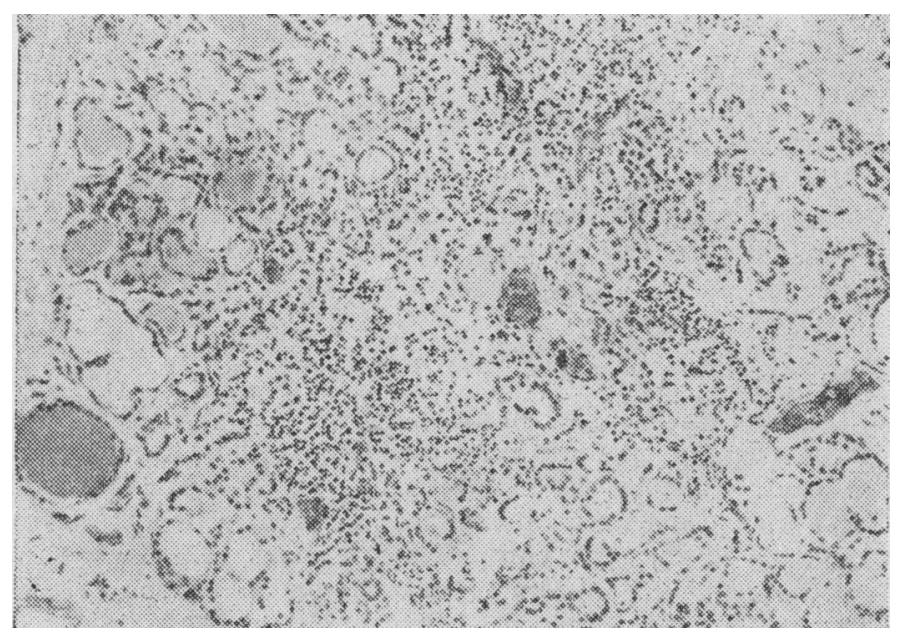

Fig. 3.-Thyroid. Round-cell infiltration with glandular atrophy and absence of colloid. ( $H$. and $E$. $\times 120$.) characterized by acinar atrophy, fibrosis, and lymphocytic infiltration. No lymphoid follicles or Askanazy cells can be seen.

Stomach (Fig. 4).-The mucosa and muscle coats of the body are severely atrophied. The mucosa is heavily and diffusely infiltrated with lymphocytes. The glands show a simple tubular mucus-secreting pattern; no parietal cells are recognizable. The muscularis mucosae is also highly infiltrated with lymphocytes.

Adrenals (Fig. 5).-There is bilateral cortical atrophy. The cells of the cortex are predominantly pale finely vacuolated cells; a few small groups of eosinophilic compact cells are also present. At some sites immediately below the thickened fibrosed capsule groups of cells show an acinar pattern. No lymphocytic infiltration or degenerative changes occur in the cortical cells.

Sections of the pancreas and hypothalamus show no abnormality.

\section{Discussion}

Though the patient was incompletely investigated, there seems little doubt that she had progressive hypopituitarism, death resulting from adrenal and thyroid insufficiency precipitated by bronchopneumonia and possibly the administration of promazine.

This combination of lesions-namely, anterior hypophysitis, chronic atrophic gastritis, focal lymphocytic thyroiditis, and adrenal atrophy-has not previously been reported.

The findings in the pituitary were similar to those reported by Goudie and Pinkerton (1962). Their case was that of a young

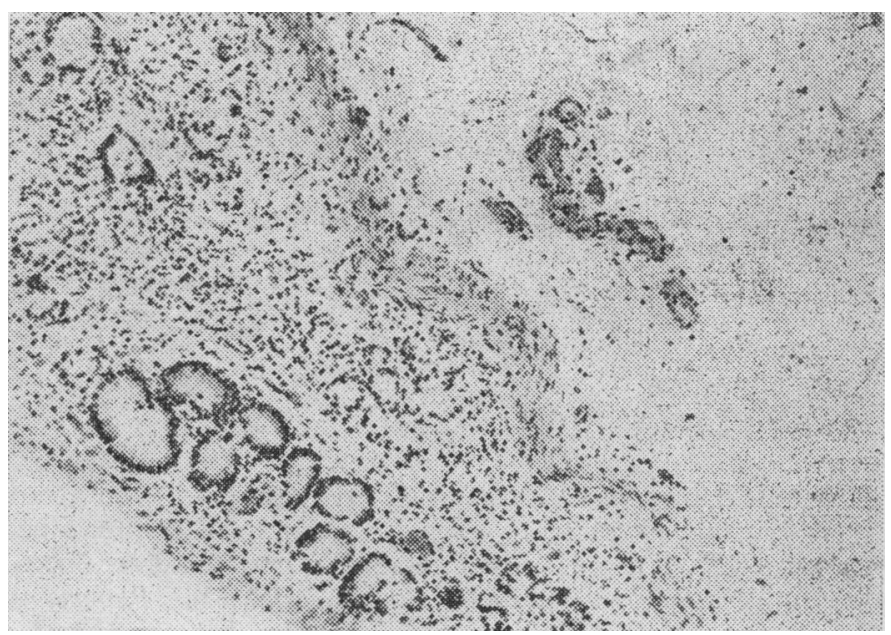

FIG. 4.-Stomach. Chronic atrophic gastritis showing mucus-secreting glands and lymphocytic infiltration. (H. and E. $\times 120$.)

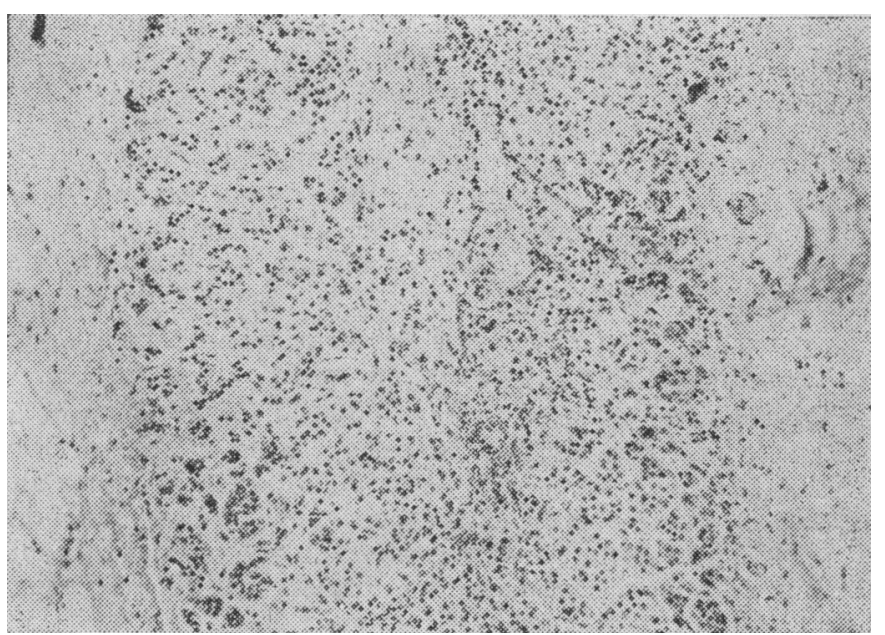

Fig. 5.-Adrenal. Cortical atrophy with fibrous thickening of capsule and acinar pattern in outer zone. (H. and $E . \quad \times 85$.) 
woman, six months postpartum, who gave a history suggestive of progressive hypopituitarism and died of adrenocortical insufficiency after appendicectomy. They also found that the thyroid showed Hashimoto's disease. No mention was made of the stomach, and the adrenals could not be found at necropsy. In neither case are the histological changes in the pituitary those seen in healed postpartum necrosis (Sheehan and Summers, 1949) or in giant-cell granuloma of the pituitary (Oelbaum and Wainwright, 1950 ; Doniach and Wright, 1951).

The adrenals in the present case show the features secondary to prolonged hypopituitarism. Though no Askanazy cells or lymphoid follicles with active germinal centres are present in the thyroid, the acinar atrophy with fibrosis and lymphocytic infiltration is now regarded as being sufficient for the diagnosis of focal lymphocytic thyroiditis. This is believed to be a focal form of Hashimoto's disease (Doniach, 1960). Its incidence in elderly women and association with complement-fixing antithyroid antibodies have been shown by Goudie et al. (1959).

It would seem reasonable to suggest that the coexistence of the anterior hypophysitis, focal thyroiditis, and atrophic gastritis with pernicious anaemia is not fortuitous. Pernicious anaemia and chronic thyroiditis are now believed to be diseases in which autoimmune processes play an important part. In the present case the pituitary, thyroid, and gastric changes may be explained by the onset of autoimmune reactions to these three glands. It seems likely that the process had been present since at least the time of her first admission to hospital in 1963. Goudie and
Pinkerton (1962) suggested that the autoimmune process in their case might have been related to the release of antigens after puerperal involution of the pituitary and thyroid. There is no obvious precipitating factor in the present case. We suggest that anterior hypophysitis of possible autoimmune origin has now to be added to the list of aetiological factors causing hypopituitarism.

\section{Summary}

A case is reported of hypopituitarism in a woman aged 74 who suffered from pernicious anaemia. The anterior pituitary and thyroid showed acinar atrophy, fibrosis, and lymphocytic infiltration, and the stomach showed changes of chronic atrophic gastritis. We suggest a possible autoimmune basis for all three lesions.

Thanks are due to Mr. G. R. Headden for the photomicrographs.

\section{REFERENCES}

Doniach, I. (1960). Recent Advances in Pathology, edited by C. V. Harrison, 7 th ed., p. 242 . London.

- and Wright, E. A. (1951). 7. Path. Bact., 63, 69.

Goudie, R. B., Anderson, J. R., and Gray, Kathleen G. (1959). Ibid., $77,389$.

and Pinkerton, P. H. (1962). Ibid., 83, 584

Oelbaum, M. H., and Wainwright, J. (1950). F. clin. Path., 3, 122

Sheehan, H. L., and Summers, V. K. (1949). Quart. F. Med., 18, 319.

\section{Preliminary Communications}

\section{Preliminary Report on Tyramine Headache}

\section{Brit. med. F., 1967, 2, 550-551}

It is well known that a small minority of patients who give a typical history of migraine believe that certain foods precipitate their attacks. The foods most commonly implicated are chocolate, milk and milk products, alcohol, and fish. Reports of investigations into food factors in migraine have produced a variety of conflicting results, ${ }^{1-7}$ but no reason for this reaction to certain foods has been established.

In the past three years Blackwell and his associates (Blackwell, ${ }^{8}$ Blackwell and Mabbitt, ${ }^{9}$ and Blackwell and Marley, ${ }^{10}$ ) have reported that patients being treated with monoamine oxidase inhibitors occasionally develop severe headaches after eating cheese, and they have shown that these headaches are due to the absorption of tyramine from the cheese owing to the inhibition of monoamine oxidase, the enzyme responsible for the breakdown of tyramine in the intestine. Other foods which caused the same effect were mentioned by Blackwell and Marley. ${ }^{10}$

On reading these reports the similarity between their list of foods and those that can precipitate migraine was apparent.

Table I gives a list of foods mentioned in the literature as migraine precipitants. For comparison a list is also given of foods which are known to have produced severe headache and pressor reactions in patients on monoamine oxidase inhibitors. It may well be that tyramine is not the only amine that could be concerned in the headache due to diet, but this preliminary investigation is concerned with tyramine only.

Since migraine is a hereditary disorder, some migraine sufferers might have a genetic enzyme deficiency (possibly of monoamine oxidase). Such a deficiency might lead occasionally to increased amine levels in the blood stream. A possible explanation of some attacks of migraine may be that certain people have a particularly sensitive localized vascular response to circulating amines such as tyramine.

TABLE I.-Food Mentioned in Literature as Migraine Precipitants

\begin{tabular}{|c|c|c|c|c|}
\hline \multicolumn{3}{|c|}{ Food } & \multirow{2}{*}{ 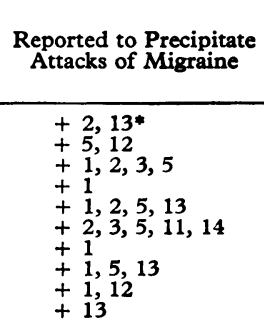 } & \multirow{2}{*}{ 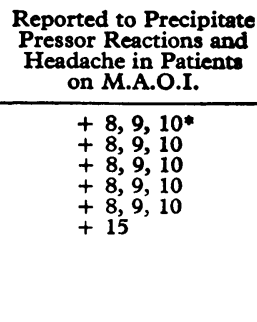 } \\
\hline $\begin{array}{l}\text { Alcohol } \\
\text { Cheese } \\
\text { Fish } \\
\text { Beans } \\
\text { Milk dair } \\
\text { Chocolate } \\
\text { Eggs } \\
\text { Wheat } \\
\text { Nuts } \\
\text { Tomatoes }\end{array}$ & 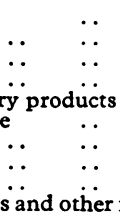 & $\begin{array}{c}\ldots \\
\because \\
\ldots \\
\because \\
\because \\
\because \\
\ddot{o d s}\end{array}$ & & \\
\hline
\end{tabular}

On the basis of these suggestions an experiment was designed to ascertain whether migraine attacks could be precipitated by giving patients tyramine by mouth.

\section{METHOD}

Patients who gave a history of a clear dietary relationship to their attacks of migraine were selected from those attending the migraine clinic at the Elizabeth Garrett Anderson Hospital. The original diagnosis of migraine had been made by a neurologist in all these patients. Though about half the patients questioned gave a history of food factors in relation to their attacks, the information was often unreliable, being influenced by various factors such as articles read in health journals. Where the implicating factors were so diffuse as to invalidate 